ISSN: 2224-0616

Int. J. Agril. Res. Innov. Tech. 10(1): 94-96, June 2020

DOI: https://doi.org/10.3329/ijarit.v10i1.48099

\section{OPEN 2 ACCESS}

Available online at https://ijarit.webs.com https://www.banglajol.info/index.php/IJARIT

\title{
A novel method to test for lead contamination in soil around US schools
}

\author{
H. Garcia ${ }^{1 *}$ and R. Palacio ${ }^{2}$ \\ Received 18 April 2020, Revised 18 May 2020, Accepted 20 June 2020, Published online 30 June 2020
}

\section{A B S T R A C T}

It has been rumored that soils around schools in the US are contaminated with lead, which is known to be harmful to children, and is known to inhibit plant growth. The purpose of this study is to investigate the growth of plants in soil sampled from US schools to see if decreased plant growth can indicate lead contamination before testing is done. After comparing the time until germination, height, and root length of radishes grown in soil from the surrounding area of the school to that of those grown in uncontaminated soil, we found that radishes grown in soil from schools germinated at a rate $38 \%$ slower than radishes grown in uncontaminated soil $\left(\mathrm{HR}=0.62,95 \% \mathrm{CI} 0.33-1.2, \mathrm{P}_{\text {trend }}=0.13\right)$. The mean radish heights between the two groups were also found to be significantly different $(p=0.12)$. Decreased plant growth may serve as an indicator for soil contamination before other laboratory tests are done. It is recommended that further testing for lead and other toxins should be conducted on the soil of the surrounding area, and larger studies with multiple species of plants should be conducted to see if these trends could be applied to the general plant population around schools.

Keywords: Lead, Germination, Growth, Height, Root length, Contamination.

${ }^{1}$ Northeastern University, Boston, MA, 02115, USA.

${ }^{2}$ State University of New York at Buffalo, Buffalo, NY, 14260, USA.

*Corresponding author’s email: garcia.ha@northeastern.edu (H. Garcia)

Cite this article as: Garcia, H. and Palacio, R. 2020. A novel method to test for lead contamination in soil around US schools. Int. J. Agril. Res. Innov. Tech. 10(1): 94-96. https://doi.org/10.3329/ijarit.v10i1.48099

\section{Introduction}

Soil contaminated with lead from leaded gasolines has been an ongoing public and environmental health problem in all industrialized countries who have used cars with internal combustion engines until around the 1990s (Laidlaw et al., 2012). Although lead is a known neurotoxin in humans, the effects of lead on the growth of plants are relatively unknown. While plants have developed mechanisms to deal with living in environments containing high concentrations of heavy metals such as rapidly absorbing lead into their roots to create a diffusion gradient towards the external environment or developing calluses on their root hairs, previous studies have only investigated the methods plants use to mitigate lead toxicity, not how such toxicity affects plant growth (Lin et al., 2004; Bacic et al., 2009; Krzesłowska, 2011; Samardakiewicz et al., 2012). One previously conducted study investigated the effects of lead on root growth but failed to present the effects of lead on germination time and plant height, factors that are necessary to completely understand the effects of lead on the life cycles of plants (Fahr et al., 2013). This study exhibits the effects of lead contamination on plant growth and demonstrates how the observation of decreased plant growth in untested soil can be used as an indicator of soil contamination.

\section{Materials and Methods}

The researchers (HG and RP) collected soil samples from schools in Clarkstown Central School District in the state of New York and chose Raphanus raphanistrum due to its history as a model organism. The two egg cartons, one plastic and one cardboard, contained a total of 42 cells, 21 of which were filled with the contaminated soil and the remaining filled with the uncontaminated soil. Three radish seeds were planted in each cell and the cartons were placed under a grow light, positioned to give the control and experimental groups an equal exposure to light. Each cell was given $10 \mathrm{~mL}$ of water each day. The plants were then transferred to the residence of RP where he measured and entered data in Google Sheets while HG conducted the statistical analyses and authored the manuscript.

Google Sheets and Microsoft Excel 2016 were used to compile data and $\mathrm{R}$ was used for basic data analyses. The "survival" and "survminer" $\mathrm{R}$ packages were used to estimate Cox Proportional 
Hazard models for how the contaminated soil affects seed germination compared to seed germination in the uncontaminated soil over time. 2-sample t-intervals were also calculated for the relationships between soil contamination and the following measurements: germination time, height in $\mathrm{cm}$ measured 3 days from germination, and root length measured 5 days after germination. Hazard ratios (HR) and $95 \%$ Confidence Intervals (CI) were then modeled to estimate the ratio of the probability of germination over time between the two soil types. Alpha was not set as the nature of the small sample creates the need for more leniency when interpreting $\mathrm{p}$-values as the results, instead of serving as an estimate of the population, should only elucidate the need for larger, future studies testing plant health in the soil around CHSN. Only one-sided $\mathrm{p}$-values are presented in the results.

\section{Results}

The final Cox proportional-hazard model (Figure 1) demonstrates that the radishes grown in lead contaminated soil germinated at a rate $38 \%$ slower than radishes grown in uncontaminated soil $\left(\mathrm{HR}=0.62,95 \%\right.$ CI $\left.0.33-1.2, \mathrm{P}_{\text {trend }}=0.13\right)$. When controlling for the presence of lead in soil, taller radishes tended to germinate at a 10\% higher rate than smaller radishes ( $H R=1.1,95 \%$ CI $0.97-1.3, P_{\text {trend }}=0.12$ ), while no association was determined between root length and germination time $(\mathrm{HR}=1.0,95 \% \mathrm{CI}$ 0.97-1.1, $\left.P_{\text {trend }}=0.32\right)$. Two-sample t-tests $($ Table 1$)$ also revealed significant differences in the germination times and radish heights between the two groups ( $p=0.15$ and 0.12 , respectively), but no significant difference between the mean root lengths of radishes grown in the two soil types was revealed $(\mathrm{p}=0.33)$.

\section{Figure 1. Cox proportional-hazards model of plant germination time and soil type}

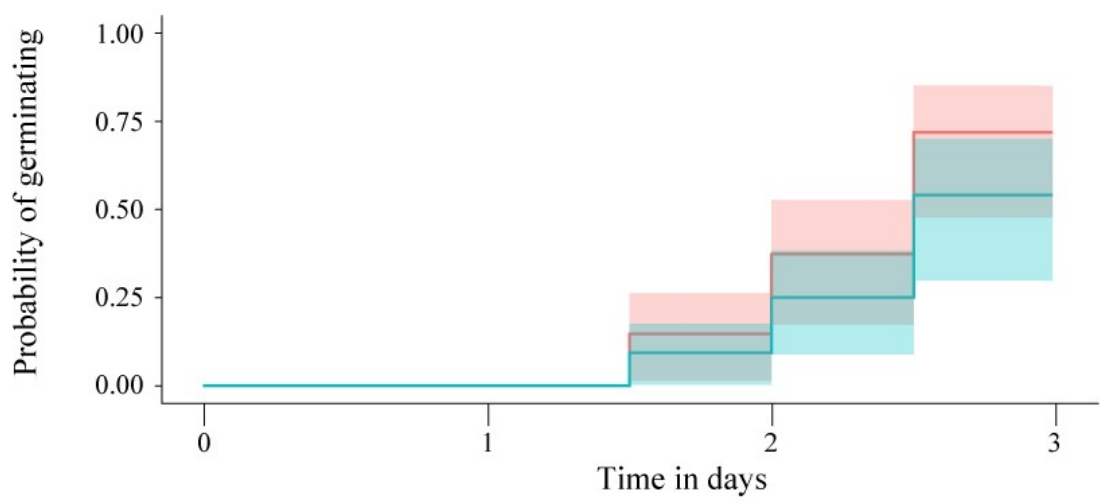

Legend

- No lead

- Lead

Time at which the seed germinated was Probability of all seeds germinating, and 95\% considered to be the event in the model. Data is confidence intervals are plotted over a period of 3 right censored as some seeds did not germinate. days.

Table 1. Results of hazards modelling between all factors.

\begin{tabular}{|c|c|c|c|c|c|}
\hline \multicolumn{6}{|c|}{ Cox proportional-hazard models } \\
\hline & Beta & HR & $95 \% \mathrm{CI}$ & Wald test & $P_{\text {trend }}$ \\
\hline Soil \& Germination & -0.490 & 0.62 & $0.33-1.2$ & 2.30 & 0.13 \\
\hline Height \& Germination & 0.100 & 1.10 & $0.97-1.3$ & 2.40 & 0.12 \\
\hline Root \& Germination & 0.035 & 1.00 & $0.97-1.1$ & 0.98 & 0.32 \\
\hline \multicolumn{6}{|l|}{ 2-sample T-tests } \\
\hline & T value & $\begin{array}{l}\text { Degrees of } \\
\text { freedom }\end{array}$ & P value & & \\
\hline Germination & 1.04 & 37.23 & 0.15 & & \\
\hline Height & 1.20 & 38.35 & 0.12 & & \\
\hline Root & 0.43 & 38.59 & 0.33 & & \\
\hline
\end{tabular}


Cox proportional hazards models were run between all classes of data collected. 2-sample ttests were also computed between measurements of plants in contaminated vs. clean soils.

\section{Discussion}

Currently, this is the only study investigating how lead contaminated soil affects plant germination time, height, and root length via a Cox proportional-hazards model; this is also the first study to develop an easy method to test for contaminated soil without molecular analysis. The soil tested positive for high lead after analysis by a lab contracted by the school district; from this, it can be inferred that the lead inhibited plant growth, and that lower than normal plant growth may serve as an indicator for soil contamination. It is suspected that these soils were contaminated due to leaded gasoline used in the 1950s (Smith and Flegal, 1995).

The results could have larger implications regarding local and community agriculture. The presence of school gardens have increased over the past decade; if these plants are grown in contaminated soil, it could have negative health effects on the school children (Graham et al., 2005). Community farms and gardens around the schools or areas with contamination may also be adversely affected, but the detection of contaminated soil may now be indicated by growing the same species of plant in a soil of clean and in a soil of unknown status and comparing the time to germination.

Although no relationships under a p-value of 0.05 have been found in the results, it is unusual to obtain such p-values with small samples. Significant results were seen in the hazards modeling as the confidence intervals did not overlap in the final day. Future studies should be conducted with larger sample sizes in better controlled environments as we had problems with the cardboard egg carton absorbing water from the soil, decreasing the amount of water for the plants, and buckling from the weight. Although equal amounts of cells from the control and experimental groups were grow in the cardboard carton and the rules of means dictate that such decreases in heights from both samples do not compromise the results of this study, total uniformity may have yielded different results. A further problem is that we had to exclude data from one of the leaded cells as the seeds did not germinate; we felt that such an exclusion would provide more realistic results rather than censoring the germination data point at 6 days and including it as an outlier.

Results should be interpreted with caution due to small sample size and due to limited number of species of plant used. Further research should establish the mechanisms behind delayed germination and should test more soil samples to confirm the results.

\section{Conclusions}

This study indicates that there may be significant decreases in germination time and height of plants grown in lead contaminated soil compared to plants grown in uncontaminated soil. It also introduces an easy way to screen for lead in soil without intensive lab analyses, but larger studies should be conducted on different types of plants to see if such relationships exist in other species. The soil around schools should be tested for lead and cleaned if the concentrations of heavy metals and other toxins are high enough to pose health threats.

\section{Acknowledgements}

This study was conducted without any funding, and the authors have no competing interests.

\section{References}

Bacic, A., Fincher, G.B. and Stone, B.A. 2009. Chemistry, biochemistry, and biology of 1-3 beta glucans and related polysaccharides. $1^{\text {st }}$ Edition, Academic Press. USA. 35op.

Fahr, M., Laplaze, L., Bendaou, N., Hocher, V., El Mzibri, M., Bogusz, D. and Smouni, A. 2013. Effect of lead on root growth. Frontiers in Plant Sci. 4: 175.

https://doi.org/10.3389/fpls.2013.00175

Graham, H., Beall, D.L., Lussier, M., McLaughlin, P. and Zidenberg-Cherr, S. 2005. Use of school gardens in academic instruction. $J$. Nutr. Edu. Behav. 37(3): 147-151. https://doi.org/10.1016/S1499-4046(06)60269-8

Krzesłowska, M. 2011. The cell wall in plant cell response to trace metals: polysaccharide remodeling and its role in defense strategy. Acta Physiol. Plant. 33: 35-51. https://doi.org/10.1007/s11738-010-0581-z

Laidlaw, M.A., Zahran, S., Mielke, H.W., Taylor, M.P. and Filippelli, G.M. 2012. Resuspension of lead contaminated urban soil as a dominant source of atmospheric lead in Birmingham, Chicago, Detroit and Pittsburgh, USA. Atmosph. Environ. 49: 302-310.

https://doi.org/10.1016/j.atmosenv.2011.11.030

Lin, Q., Chen, Y.X., He, Y. F. and Tian, G.M. 2004. Root-induced changes of lead availability in the rhizosphere of Oryza sativa L. Agric. Ecosyst. Eviron. 104(3): 605-613.

https://doi.org/10.1016/j.agee.2004.01.001

Samardakiewicz, S., Krzesłowska, M., Bilski, H., Bartosiewicz, R. and Woźny, A. 2012. Is callose a barrier for lead ions entering Lemna minor L. root cells? Protoplasma. 249(2): 347-351. https://doi.org/10.1007/s00709-011-0285-2

Smith, D.R. and Flegal, A.R. 1995. Lead in the biosphere: recent trends. Ambio. 24(1): 2123. Retrieved from

https://www.jstor.org/stable/4314280. 